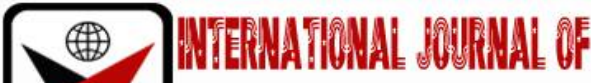

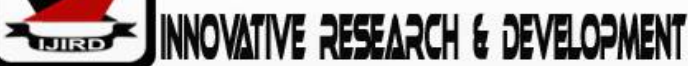

ISSN 2278-0211 (Online)

\section{Literacy, Literature and Gender Conflict: A Reading of Ola Rotimi's Our Husband Has Gone Mad Again and Tracie Chima Utoh's Our Wives Have Gone Mad Again}

\author{
Ugwanyi Dele Maxwell \\ Lecturer, Department of English and Literary Studies \\ Enugu State University of Science and Technology Enugu Nigeria
}

\begin{abstract}
:
In the society, the gender roles of the men are seen as being superior to that of the women. The women are placed at a very low status. It is for this reason that African female and male writers began to write to expose the ways in which the rights of the women are violated and how they should try to gain freedom from this violence. Literacy has been identified as the most potent weapon in this direction through the instrumentality of literature. Ola Rotimi and Tracie Chima Utoh are among the literary writers who have used female characters as tools for social, political and economic change. This research paper is an attempt to investigate the relationship between literacy and literature vis-vis gender conflict and consciousness. The paper also looks at the level of awareness required by both genders in the liberation struggle. The paper concludes that literacy and literary consciousness is an indispensable tool in the sustenance of gender harmony both in the family and social cycle.
\end{abstract}

Keywords: Gender conflict in African drama, issues in Ola Rotimi's plays, Tracie Utoh's plays, Gender roles in African Literature, Literacy and gender constructions

\section{Introduction}

Gender is a range of characteristics of femininity and masculinity. Depending on the context, the term may refer to such concepts as sex (as in the general state of being male or female), social roles (as in gender roles) or gender identity. Sexologist John Money introduced the terminological distinction between biological sex and gender as a role in 1955. Before his work, it is uncommon to use the word 'gender' to refer to anything but grammatical categories. However, Money's meaning of the word did not become widespread until inthe 1970's, when feminist theory embraced the distinction between biological sex and the social construct of gender. Today, the distinction is strictly followed in some contexts especially in the social sciences and documents written by the World Health Organization (WHO), but in many contexts, even in some areas of social sciences, the meaning of gender has expanded to include 'sex' or even to replace the latter word.

Although, this gradual change in the meaning of gender can be traced to the 1980, a small acceleration of the process in the scientific literature was observed when the Food and Drug Administration started to use 'gender' instead of 'sex' in 1993. 'Gender' is now commonly used even to refer to the physiology of non-human animals without any implication of social gender roles.

\section{Gender Roles}

Gender roles are cultural \& personal. They determine how males and females should think, speak, dress and interact within the context of the society. Learning plays a role in this process of shaping gender roles. These gender schemas are deeply embedded cognitive frameworks regarding what defines masculine and feminine. While various socializing agents - parents, teachers, peers, movies, television, music, books and religion - teach and reinforce gender roles throughout the lifespan/parents probably exert the greatest influence especially on their very young offspring.

As mentioned previously, sociologists know that adults perceive and treat females and males infants differently. Parents probably do this in response to their having been recipients of gender expectations as young children. Traditionally, fathers teach boys how to fix and build things: mothers teach girls how to cook, sew and keep the house clean. Children then receive parental approval when they conform to gender expectations and adopt cultural accepted and conventional roles. All of this is reinforced by additional socializing agents, such as the media. In other words, learning gender roles always occurs within a social context, the values of the parents and society being passed along to the children of successive generations. 
Gender roles adopted during childhood normally continue into adulthood. At home, people have certain presumptions about decision-making, child rearing practices, financial responsibilities and so forth. At work, people also have presumptions about power, the division of labour and organizational structures. None of this is meant to imply that gender roles in and of themselves are good or bad; they merely exist. Gender roles are realities in almost everyone's life.

Gender conflict is a situation whereby men and women fight to have equal rights. This equal right has to do with the ability to perform any societal role. This gender conflict has to do with a man fighting to have the right to do whatever any woman can do and the women in turn fighting to have the right to do whatever a man can do. Nobody's role should be seen as being inferior but equal.

In the world today, women are the ones placed in the position to fight for equal rights with the men because they are the ones that are allegedly being oppressed. Their roles are seen as inferior while the men's roles are seen as superior. According to the present day cultural and biological adaptation, women have been seen as the inferior ones and thus, possessing the minor roles.

Men try to maintain the superior rights and privileges that they hold in the society while the women have said 'No' to this dominance and have decided to right to have equal rights with the men.

\section{Origin of Gender Conflict}

By living in rural society, close to nature, the gender roles of male and female; boy and girl; young and old were clearly defined. Women did not seek to compete with men because it was obvious that women could not cut down trees, so, they were content doing house works. There was indeed a lot of houseworks for women and girls to do for thousands of years.

Even the Christian religion portrays Eve as an afterthought produced from the spare rib of Adam. The status of Eve was made inferior and subjected to the authority of man. This is because the origin of human suffering is held to have its source in Eve.

In a similar vein, Armstrong (1993) Holms and Bowker (1994) argue that none of the major religion has been particularly good to women. They have usually relegated women to a marginal position thereby, reinforcing and sustaining gender inequality in the society.

The origin of gender conflict can be traced to the social consequences of the biology of human reproduction. In early human history, life was short due to malnutrition and ravaging diseases. The mortality rate was high mostly in children. About 50 percent of all children died before the age of 5 . As an adaptive mechanism, many children had to be born to make up for the dead ones. It is only the woman who gets pregnant, carries a baby or babies. Consequently, women's roles became limited to child care and home activities for a considerable part of their lives. In order to survive, a child needs a nursing mother. With a child at her breast or back, women became physically encumbered and their activities restricted to the home and child care. This made women to be dependent on men.

Women are always at disadvantage because of their biology; menstruation, childbirths and menopause. All the above have been physical burden to women but pregnancy and breast - feeding have the most serious social consequences. When women are pregnant or nursing babies, they are dependent on men whether husband, lover, brother etc. for physical survival.

In the face of dependence, men become dominant. Men go for hunting, build houses and meet other survival expectations of the women. Thus, the role men play becomes not only valued but also prestigious. In contrast, little prestige and values were given to the activities of the women. This marked the beginning of female minority status in the society.

Women said 'No' to these discriminations. They said that they could do what men could do. As a result of moving into an industrial and technological society, all hell broke loose regarding the roles of men and women; boys and girls. All of a sudden women sought to get the upper - hand over men in all areas of human activity.

Feminist promoted the wicked myth that women have been 'oppressed' by men for thousands of years and that 'now it's our turn'. But the truth is that women cannot do some of these activities because they are not physically strong enough to handle the activities.

Up till date, feminist continue to encourage girls to go into obscure male dominated occupations even if they do not have interest in them. This is encouraged so that the women can show the men that 'whatever a man can do, a woman can do better'.

\section{Definition of Terms}

\subsection{Gender}

This means the condition or fact of being a male or a female. Recognizably and most commonly in the society today, a human being is either a male or a female.

\subsection{Conflict}

A concerted effort or campaign to combat or put an end to something considered injurious. In an attempt to put an end to this injurious practice, competition between the parties involved (That is, the male and female) may occur. In this context, there is the competition between the male and the female. 


\subsection{Gender Roles}

A pattern of masculine or feminine behaviour of an individual that is defined by a particular culture and that is, largely determined by a child's upbringing. It refers to the set of social and behavioural norms that are considered socially appropriate for individuals of a specific sex in a context of a specific culture. These roles differ widely between cultures and historical periods.

\subsection{Male Dominance}

The act of men being more important, powerful and noticeable than the women. Many critics have written about gender conflict, that is, men and women fighting to have equal rights.

Mariama Ba wrote about women in modern African society. Her works explore the agony and dilemma and the pleasures and triumphs of women like herself who are caught between two diametrically opposed worlds; traditional African and modern societies.

Ba's juxtapositions of various marriages highlight the status of women in contemporary African society. These women live in a society that seems to be designed primarily to keep them subjugated. The men enjoy unlimited freedom, choosing and discarding wives as they wish, while the women are expected to keep silent and accept their lot in accordance with the divine will of Allah.

In So Long a Letter (1980), Ba's first and major novel, she began what was eventually to become the major theme of her fiction - the plight of women in Muslim societies such as Ramatoulaye and her friend and confidante Aissatou, who after many years of marriage find themselves relegated or discarded by their husbands for younger brides. The novel focuses on how each of these women try to cope with the trauma of being cast aside after giving so much, including bearing many children. Ramatoulaye grieves for her husband, Modou Fall, who has just died of a heart attack, while the family makes arrangement for the funeral. The funeral and the activities of her in-laws prompt Ramatoulaye to seek escape through a long letter to Aissatou. When faced with having to cope with a co-wife, Aissatou decides to divorce her husband, Mawdo, and return to school. Eventually she secures a plum job as an interpreter at the Senegalese embassy in New York. Ramatoulaye's letters turn out to be a sustained account of the emotional and psychological trauma that she has been through in the years proceeding Modou's death. She knows Aissatou will understand because she has gone through a similar experience. So as Ramatoulaye touches on their shared experiences, which are similar to those or other oppressed Senegalese Muslim women, she ends up writing her 'so long a letter'.

The men forget that for their wives, marriage means a union between two and only two individuals to be sustained through caring and sharing. Edris Makward points out in his essay of Ba:

'Two initially successful marriages, between Mawdo and Aissatou and Ramatoulaye and Modou ended in failure is partly due to Mawdo mother's efforts to correct what she considered her son's misalliance, his marriage with a member of a lower caste. The letter is simply caused by Modou's infatuation with a much younger woman (p. 278).

In Efuru, a woman that cannot produce is not a woman. The richest woman on earth is the poorest without a child. Efuru remains quite attached to the tradition by which the wife participates in the search for a new mate:

What is wrong in his marrying a second wife? It is only a bad woman who wants her husband all to herself. I don't object to his marrying a second wife, but I do object to being relegated to the background. I want to keep my position as the first wife for it is my right (p.53).

No matter how little the right, the woman wants to have it.The male writer like the male social animal is more fortunate than the female. Cultural misconception and taboos abound. It is believed that women must keep quiet when men are talking. Woman is women, mother, child bearer, supporter of man. If a woman talks too much she is considered uncivilized. If she is educated, she is classified as a weird specimen:

Fortunately, taboos die - though slowly with the times. With the new warped, so called luminaries emerging from the colonial roots even the female deaf and dump have acquired a voice. It is a voice of confusion, confrontation of commitment. The man have had their say, they continue to have it. It is now the women turn (23)

Ezeigbo also has been referred to as a feminist she states that:

'People keep talking about me being a feminist writer, I don't really see it like that. I am not the type that will come out and begin to make noise, I am not a feminist, well and good. But remember, what is feminism after all? It is just a principle that posits that men and women should have equal rights. That's all feminism is all about (6).

Chinyere Okafor (1999), who is seen as repudiation (a person who rejects) of the more extreme Western version of feminism states that; 'African feminism does not subscribe to a monolithic and exclusive empowerment of women, her family, and her male relations' (59).

Barbara Smith(2004) in her article 'This Bridge called my Back' views feminism as: 'The political theory and practice to free all women, women or colour, working class women, poor challenged women, old women. Anything less than this is not feminism...' (23). This woman has the ideology that everything should be done in favour of women, they should be tried from all political and economic situations. In the contemporary Nigerian probe, Akachi Adimora - Ezeigbo and Kaine Agary are among the writers who have striven to show the plights of our Nigerian women in a patriarchal society. These writers have brought out the importance of gender equality for the progress of the society. Barry Peter in his Beginning Theory assesses the novel, Children of the Eagle as 'what might be called mechanisms of patriarchy's that is, the cultural mind set in women and men which perpetuated sexual inequality' (122). 
However, in African society and traditions, some writers have shown great concern to the issue of gender conflict. Tess Onwueme in her play The Reign of Wazobia shows the resistance of women to cultural oppression. In the play, Wazobia rules the women with the assistance of the Omu and thus, conquers their men who plan to dethrone her even though she has not ended her reign of three seasons. She is adopted into the play by Tess Onwueme to show the role of women in their struggle for leadership which they finally achieved. Thus, towards the end of the play, Big says: 'We have taken over the stage, women have taken over the stage' (35).

In the Wedlock of the gods, Zulu Sofola adopts characters like Ogwuoma to show the psychological and physical state or condition which women pass through. They are in bondage all because of the so called custom of the land.Ugwuoma is forced to marry Adingwu by her parents because they need the bride price to take care of their son who is sick. Ogwuoma has been in love with Uloko, a poor man and thus, hates Adiugwu knowing fully well that she cannot marry Uloko. The opportunity comes for her to be free and this is the death of her husband but the wicked tradition states that she is to be inherited by her dead husband's brother, she is still in bondage. The psychological torture is much that she sleeps with Uloko in the period of mourning and thus, for her actions, she experiences 'a swelling of the body with water leaking from everywhere'. (19). Zulu is one of the playwright who feels and portrays women as willing slaves of African tradition. This is one thing that the females kick against.

Onuora Nzekwu in his Highlife for Lizards portray the characters of Agom who is head strong and insists on carrying out her desire of marring a man of her choice, thereby, setting aside societal norms and defeating the males. By doing this, the role of Agom is uplifted and her freedom granted.

In Ola Rotimi's Our Husband Has Gone Mad Again, we see men and women fighting for equal rights. They make efforts to see that they are not looked down on, to ensure that they prove to the world that they can do whatever their counterparts can do.

Although, this play is centered more on the women fighting for their right and freedom in a male dominated society, Lejoka Brown, the protagonist tries to be equal with his wife Liza in terms of education by going into politics.

Major Rahman Lejoka - Brown resigns from the Army and takes up his father's cocoa farm which is falling to pieces. He marries women as if they are mere property for his selfish reasons and when he is done with them, he discards them. He meets Liza, a Kenyan, medical student in Stanleyville during the 'Congo thing'. One day as their infantry are mopping up pockets of guerilla resistance, a Belgian mercenary Caward wires SMG into his thigh. He is rushed to the hospital and Liza takes very good care of him. 'Two Months after', they go to the marriage Registry and fix things up.

As for Mama Rashida, the second wife, she is the oldest of Lejoka late brother's wives. Lejoka's elder brother died in a train accident and two days before his marriage to Liza, he receives a letter from his father. His father marries Mama Rashida off to him.

Lejoka Brown marries Sikira because of politics. 'And as for Sikira, I only wanted her to help me win the elections' (p.69). He even goes ahead to tell his friend, Okonkwo, his intentions on how he will discard them since the only person he loves to have as his wife is Liza. He says that after the elections 'I give Sikira lump sum capital to go and trade and look for another man or something like that; Mama Rashida remains right in this house of my fathers; and I move into Minister's quarters on Victoria Island. Liza joins me there; everybody is happy' (p.10).

Brown sees the running around just to put things in order and to keep the secret of having two other wives away from Liza as unnecessary. He says to his friend while waiting at the LagosInternationalAirport to pick Liza up that 'Here, I am running up and down, renting a flat, getting restless, going crazy! Just because ......I mean, I whose grandfather had a hundred and fifteen wives, I tell you.... One hundred plus ten plus five breathing wives all at once under his very roof! But here I am, with only two little crickets, expecting one more - just one more canary, and I can't just pick her by the arm and say to her: 'Women, I forgot to tell you; but as the Whiteman says; better late than never! Here - meet your other ehm............. sisters in marriage!' (p.28).

The wives that is, Mama Rashida and Sikira are submissive to the extent that they even refer to Lejoka Brown as 'my lord'. They pound, serve drinks and do all the house chores. They do not sit around their husband whenever is around. They are not bold to say whatever they want to their husband. They do not discuss with him and are ordered around and told what to do by their master.

The case is different for Liza who has stayed in America; a country in which men and women have equal rights. She is faced with the problem of adjusting to the dress code and husband and wife relationship of the African people. Instead of covering her body properly with wrapper, buba, veil, making sure that her face is well covered, the ears included, she wears short knickers, tight Capri pants and even smokes cigarettes. It is on an occasion of her indecent dressing that Lejoka - Brown commands his party members such as, the BBC correspondent, Local reporter 1 and Local reporter 2, Mallam Gaskiya his party's deputy leader and secretary - General to run into the kitchen. He tells them to sink to kneeling position on the floor while their eyes are fix to the ground so that they will not see Liza who is scantily clad in a bathing suit; a bikini.

Liza is bold enough to say whatever she wants to her husband, whereas the others are not. She plays with her husband whist the others cannot. It is during one of these love-plays, chasing one another that the third wife, Sikira runs away to her mother's house shouting 'Our husband has gone mad again!' (59).

When Liza returns from America, the submissive wives change totally. Liza forges allegiances with the wives, teaching the older one, Mama Rashida, about demand and supply so, she becomes a chicken magnate and inciting the younger, Sikira to oppose the major in his ludicrous election. According to Mama Rashida, Liza 'put big ideas in Polycarp's head'. Polycap is no longer the 'do whatever oga says' He is now bold to speak for himself as he answers when Sikira scolds him for not knocking before entering the room 'Whetin you want make I do? - Blow wisul?' (P.48). He now reads Liza's book and learns how to make cages. 
Mama Rashida on her side decides to focus on her 'big new trade' instead of staying at home all day to take care of the house. This time, it is the world of the women. Time to do whatever you wanted without being ordered around by the men.

Sikira brings up a suggestion to form a party for politics. A party for all married women, all house wives, all mothers and all housemaids. She becomes bold enough to talk to her husband. She begins to dress like Liza and calls the dress 'dress for the election victory celebrations' (p.56). Sikira refuses to be treated as a slave or housewife by her husband. She begins to believe that men and women are born equal and when she says it, Lejoka Brown is shocked and blames Liza for the sudden boldness in Sikira. Finally, she decides to leave the marriage for good.

Lejoka Brown on his part decides to go into politics so; he could measure up with his wife, Liza's education.

At last, the National Liberation Party members decide not to accept Lejoka Brown again as their candidate after the humiliation by Lejoka during their last meeting in his house. They describe his attitude as 'abjectly myopic, not to say, old -fashioned, authoritarian leadership' (p.66). After the condemnation and Madam Ajanaku, Sikira's mother, speech, the members agree to give their support to a female candidate.

After all said and done, their support is given to Sikira. Lejoka Brown admits that 'we have come to a new world, brother. A women's world!' (p.71). 'He even goes on to ask Okonkwo if he is sure that he still wants to marry. Lejoka Brown's reason is 'I tried to talk to Liza; Liza ran out swearing she'd leave me forever! Seconds later, good old Mama Rashida danced in here, handed me an ultimatum and walked out!' (p.71).

As the crowd appears in a procession singing the National Liberation Party's parade song, Lejoka Brown and Okonkwo see Sikira, the party new candidate and are shocked. The crowd pass by as Sikira continue to chant 'Rise up! All women of our land! Rise up and vote for freedom, or forever be slaves!'. 'Vote.....Vote for me! It is true I am a woman, but that does not matter. It does not matter, because why? Because ...' MEN AND WOMEN ARE CREATED EQUAL!' (p.76).

Now, women have the opportunity to be nominated as candidates for election and not only the men. Sikira, Mama Rashida and Liza all stand up to speak for themselves. They refuse to be treated like slaves and housewives by their husband, Lejoka Brown. Lejoka Brown decides to go into politics inorder to measure up with his wife, Liza's education. All these characters fight to have equal rights through their effort such as being outspoken, bold and going into politics.

Gender conflict in Tracie Chima Utoh's Our Wives Have Gone Mad Again is viewed as a post feministic play. This tells the position that the women who are fighting for equal rights with the men now, will be in future. By this time, they will climb the ladder to play the societal roles that men are playing now and then, the men playing theirs.

In situation one, we see even a woman after fighting for her rights climbs the ladder or the great height in politics while she oppresses the man, her husband, Mr. Inyang. This time, women whom were oppressed by the men, whom were not allowed to have equal rights with the men, became great as they took to the previous societal roles of the men, and the men took to their previous societal roles. These men are being insulted, oppressed and dehumanized. This situation opens with Ene coming into the house. She sees a living room which is yet to be cleaned. She surveys the room with disgust and disapproval and calls on her husband. She insults while ordering him to clean up the house. Ene, reduces her husband to a mere servant. Inyang is ordered around the house to serve drinks to Ene and her friends, Fummi and Mairo. At the same time, he runs around to ensure that the food is ready and he serves it on the dining table. His wife Ene, insults and calls him names like, 'lazy, Idiot', 'This useless Inyang'. 'Eunuch 'Worthless good for nothing', 'Jobless parasite' whenever he makes any little mistake in the cause of his service to her.

The situation gets so bad that Ene gives Inyang money to pay her dowry. She clothes him, feeds him and puts a shelter over his head. She says 'I took him to my village and give him money to pay my dowry. I sponsored the traditional marriage and the church wedding. I feed this man; I clothe him and put a comfortable shelter over his head' (p.24). A man is blamed when an issue is not forthcoming. Ene says 'He cannot even impregnate me. Three years since our wedding and nothing has happened. What am I supposed to do with a eunuch?' (p.24). 'Even Funmi, Ene's friend has the impetus to refer to Inyang as 'different grades and degrees of imbeciles' (p.23)

Ifeoma, seems to be the only one who did not fight and win for although, she is given equal right to own property like her house, cars, etc. she is still being oppressed by her husband, Zeus Longpole. Despite the fact that the women were being denied of their rights and finally got the right to be equal with the men, the reverse became the case as they began to oppress the men after they had fought and got the equal rights.

In situation two, we meet Odera, Felix and Inyang as they sit and drink in a bar. They discuss about a woman who cut off her husband private part. Afterwards, they begin to admire the bar attendant and desire to have sexual intercourse with her. The men have become good for nothing, useless, jobless, idlers, and liabilities as they sit and gossip while the women, their wives, go to get the daily bread thereby making them the head of their families as their husbands become the subjects ofbetter still servants.

When Felix goes into a room with the bar attendant to have sexual intercourse or as he says 'have a taste of heaven', his wife, chief (Mrs.) Irene Okperibe - Sabio and her friends, Ene, Funmi and Mairo enter. The other men Inyang and Odera hide just like the servants that they are. Odera bends his head and pretends to be asleep while Inyang moves stealthily to the bar and hides behind the counter. The women came in to discuss politics and as they demand for something to drink, they discover that the bar girl is not at her post. In their pursuit to find the attendant, they suspect that he will be the man who has lowered his head. Mairo goes to confront him and finds out that he is her husband, Odera. She is surprise to find her husband there. Inyang and Felix try to escape but their wives Ene and Irene respectively, catch them. Inyang, Felix and Odera try to tell lies to cover up for their mischievous act but their wives do not believe them and instead threaten to throw them out of the house. 
In situation three, a very short situation, our attention is drawn to Ifeoma's matrimonial home. Her husband comes in late after spending three days outside his home and when his wife Ifeoma questions him, he replies rudely saying 'Don't ask me such stupid questions. This is my house. I am a man! I can come and go as I like' (p.55). While exchanging words, we get to know that Ifeoma is a well-educated woman with a master degree in Economics and her husband an illiterate, but he beats her always. When the fight starts again, Ifeoma who had being advised by Ene, picks up a pestle by the corner and 'delivers him a deadly blow on the head'. Zeus slumps and passes out.

In her frightful state, she runs to tell her friends, Ene, Mairo, Chief Irene and Funmi and they all see it as selfdefence.

Situation four opens with the women, Chief Irene, Mairo, Ene and Funmi deliberating on how to achieve greater success in their election. Chief Irene who is contesting for the post of the president divorces her husband, Felix Sabio, for a new and educated husband, Mr. Gambo, a twenty-five years old man. Mairo commends the looks of Mr. Gambo 'Your new husband looks delectable. Twenty-five-year-old, Ibadan - educated Ph.D. holder, not to mention the dashing looks. He will make a lovable first gentleman' (p.60). Now, it is the other way round as the women are the ones who decide whether they want their husband or not. Mairo, Odera's wife plan on how to throw him out and marry another 'it has proved a Herculean task to get rid of Odera' (p.60).

Chief Ene calls on a retired prostitute who organizes five 'beautiful, elegant and ruthless girls' whom will track down, seduce and get their targets into compromising position. The girls are to work hand in hand with the photographers and camera men after which Rosandra, the retired prostitute will plant small wraps of cocaine in the opponents room. Chief Irene pays Rosandra very well and even promises to make her the Minister for Teenage Affairs. Irene bribes the policeman who chases Ifeoma with one hundred thousand naira and he promises to keep his mouth shut concerning the incident that leads to the death of Ifeoma's husband.

In the last situation; Chief Irene appears on stage, on a golden carrier borne by four young men, accompanied by her party stalwarts, friends, admirers and praise - signers. As she steps down from the carrier, she waves enthusiastically to the cheering crowd and then, intones her party slogan, L.P.P which stands for Liberation People's Party. She intones the aims and objectives of the party which are 'a party committed to the total liberation of the oppressed, the suppressed and the marginalized. A refuge for the widows, the orphans and the outcasts, the poor and the generality of the masses' (p.75). She thanks her supporters for nominating her as their presidential candidate during the party primaries. After this, she continues to intone her party slogan while the crowd responds. She entertains questions from the crowd, questions like why she divorced her former husband, Felix, her plans for the country about the death of her former opponents etc. but she answered intelligently.

Some person even accused her of killing their sons, brothers etc., but she denies all these while her thugs beat and drag them out. Her evil deeds uncover as the policeman whom she bribed to hide Zeus' dead body, comes in with other policemen. The policeman is about to arrest her when Gambo, her new husband, goes to a corner with one of the policeman and bribes him. Food and drinks are served and money is shared at the end of the campaign. The policeman comes on stage to say that the spectacle (Chief Irene's attempted arrest) which the crowd witnessed some minutes ago is nothing but a performance by the members of the Millennium Drama Group.

The women get the upper hand at the end as Chief Irene - Okpribe - Sabio succeeds in bribing the policemen to cover all her evil deeds and even gain the support of the crowd on her presidential election.

In conclusion, all the women in the play except Ifeoma take on the supposed societal male roles while suppressing their husbands. All the women except Ifeoma represent the liberated women who have fought to have equal rights with the men and have won. The cases become the other way round as the women decide to deprive the men of their rights. Ifeoma represents 'a yet to be liberated women'. She has got the right to own properties like houses, cars etc. but is still being maltreated by her husband. This shows that her liberation is 'half-way' or 'incomplete'.

Her husband, Zeus, represents a man who had fought against gender violence and for equal rights with the women but he did this in a violent way.

\section{Conclusion}

Women continue to fight for their rights. They continue to fight for the right to acquire and own property, to play whatever role that a man can play.

In the play, Our Husband Has Gone Mad Again, Rotimi exposes the ways in which a woman is depressed in a traditional society; home to be precise. Mama Rashida and Sikira respect and take whatever their husband, Lejoka Brown says. They do not have the right to speak for themselves as whatever their husband says is final. They rely on their husbands for all their need including financial needs. They believe that all they are good for is to sit and take care of the home.

The men see the women as mere property who can be married for whatever reason whether necessary or not.Liza, a woman who had spent all her life in the United States where women are treated equally as the men, arrived and everything changes for good. She encouraged the women and they wake up from their slumber and realize that there were things that they could do but had been left undone.

They become independent, bold and acquire knowledge which would help them in life. Lejoka Brown and Okonkwo, his friend, then terms it. 'A WOMAN'S WORLD'.

In Our Wives Have Gone Mad Again, Tracie Chima Utoh creates a future world for the women. A time when the women would have won the war and risen to the top. This time, it would be the men seeking to have equal rights with the women. Equal rights to do whatever the women do. It would no longer be a woman trying to speak up, own property or be independent, the reverse would be the case. It would be the men trying to survive in a female dominated society. 
Ene, Funmi, Mairo and Chief Irene become the bread-winner, they had the right to venture into politics while the men sit at home, cook and do the house - chores. Ene, Funmi, Mairo and Chief Irene are now the independent ones while the men are dependent.

Women who were initially oppressed and enslaved have now been released from the bondage of gender oppression of all kinds.

There are serious amendments for the benefit of women. For instance, women are now allowed to participate in the affairs of the society.

\section{References}

i. Ezeigbo, Akachi. Children of the Eagle. Lagos: Lantern Books, 2002.

ii. Flora, Nwapa. Efuru. Heinemann 1966

iii. Gale Cengage. Contemporary Literary Criticism 2001.

iv. Jane, Bakalaba. Honeymoon for Three. 1973.

v. Mariama, Ba. So Long a Letter.Heinemann . 1981.

vi. Nwamaka, B. Akukwe. Mariama Ba, 1929 - 1981.

vii. Ohaeto, Ezenwa. 'Preface; Our Wives Have Gone Mad Again'. Awka;

viii. Valid Publishing Company (Nig.) Ltd. 1988.

ix. $\quad$ Ojo - Ade, Femi. 'Still a Victim. Mariama Ba's Une Longue Letter'African LiteratureToday 12, 1982.

x. Okafor, Chinyere. Writing African Women: Gender Popular Cultural and Literary West Africa. Lagos: Longman. 1997.

xi. Ola Rotimi. Our Husband Has Gone Mad Again.Ibadan: OxfordUniversity Press. 1974.

xii. Onuora, Nzekwu. Highlife for Lizards. 1965

xiii. Onwueme, Tess. The Reign of Wazobia. Ibadan:Heinemann Education Books Nigeria Ltd., 1988.

xiv. Smith, Barbara. This Bridge Called my Back. California: Mayfield Publishers, 1981.

xv. Sofola, Zulu. The Wedlock of the Gods. Lagos: Malthouse Press Limited, 1989.

xvi. Taiwo, Oladele. Female Novelists of Modern African. London: Macmillan,1984.

xvii. Tricie Chima Utoh. Our Wives Have Gone Mad Again. Awka: Valid Publishing Company (Nig) Ltd. 2001. 